"tmcs-csernoch" — 2010/11/14 — 22:08 — page 247 — \#1

\title{
Teaching word processing - the practice
}

\author{
MÁRIa Csernoch
}

Abstract. I compared two surveys, which were aimed to check the word processing ability of students in high schools and universities. The surveys were carried out ten years apart from one another, in 1997 and 2006. The results clearly show that most of the students are not able to use word processors properly. In the survey of 1997 I found explanation for this underperformance in the lack of computers and teachers. However, the results of the second survey did not prove any better than the results of the first, and in 2006 neither the number of computers nor the number of teachers can be blamed. What else then? I suggest that the reason for this general ignorance, for this 'modern illiteracy' is the ignorance of the teachers. Until the teachers are not prepared and the senior students of the universities leave the education system without a proper knowledge of the required subjects, there is little chance that they would be able to teach word processing at a satisfactory level.

Key words and phrases: word processing, properly formatted text, typical mistakes, senior university students.

ZDM Subject Classification: U10.

\section{Introduction}

To what extent should in the first decade of the 21st century a young teacher, who is just leaving the education system, expected to be an expert in word processing? The answer which comes to our mind is straightforward: word processors are one of the most popular applications, students leaving universities and colleges should be professional in using them. They all started using computers in

Copyright (C) 2010 by University of Debrecen 


$$
\text { "tmcs-csernoch" — 2010/11/14 — 22:08 — page 248 — \#2 }
$$

elementary school, all of them continued their studies in high school, and by the time they reached the higher education system they became professionals, since they are required to complete their written assignments using word processors. So, the pattern is clear: we teach them in lower education, they are forced to apply their knowledge in higher education, and by the time they leave universities they are well prepared to teach and use these programs.

Had all these statements been proved correct and documented, this article would never have come to life. Some of the statements are, of course, well documented, since we have proof that students in lower education do study word processing ([17], [13]). Others, that they can use word processors properly, has not yet been proved. To prove that their knowledge is satisfactory, that is, their texts created with word processors are correctly formatted, first the criteria of the properly formatted text had to be set ([7]). According to this definition a text is properly formatted if the layout of the text is invariant to modification(s), in other words, any modification in the body of the text does not initiate its re-formatting.

Based on this definition I launched two surveys ten years apart. The first survey was carried out in the academic year of 1996-1997 ([4]), while the second in 2005-2006 ([5], [6]). In 1997 my aim was to prove that teachers of Informatics had to be aware that word processors are not simple programs, they should forget the false image that everyone can use word processors without preparation. These programs had to be taught in school, and they had to be taught with methods developed to this new subject ([3]). The second survey was launched to show that the following ten years did not prove our expectations and those who have studied word processing in school are still not able to use them properly. By analyzing the texts of these two surveys, and other texts available on the Internet, I found that one of the reasons that we have not advanced much in the past ten years is that there is no clear understanding of the concept of the properly formatted text. As a result, a definition of the properly formatted text was published in 2009 ([7]), in hope that this definition would clear up the mist on what is acceptable in word processing and what is not.

In this study I will present the results of my second survey through the now publicly available definition of the properly formatted text. 
"tmcs-csernoch" — 2010/11/14 — 22:08 — page 249 — \#3

\section{Guided texts to test the word processing ability of students}

\subsection{The subjects of the 1996-1997 and the 2005-2006 surveys}

In both surveys a guided text was selected, but the conditions were somewhat different. In the 1996-1997 survey a short text of nine lines was given to the applicants, they had to type the text and format it following the formatting requirements which were given to them ([4]). The survey was carried out in classes of junior high schools, high schools, and with the senior students of Informatics of the University of Debrecen.

In the 2005-2006 survey the senior teacher trainee students of the University of Debrecen were tested. They all were required to create a document for their final teaching session in their teacher training practice - Closing lesson plan ([1]). This document contains three compulsory and one optional parts, which are the following.

- The opening page is for the title of the document, the subject and the name of the candidate, the name of the supervising teacher (optional), and finally places for three signatures side by side at the bottom of the page.

- The next page is for data such as the place, time, class, aims, time schedule, etc. of the closing lesson plan.

- The third part, which is the main part of the document, contains the events of the lesson in the order in which they are planned to happen, the methodological remarks on the events, the tools required to complete the tasks, the participants of the events and their role in that special task. To divide the text into logically compact sections the task requires the use of at least two parallel columns, where the first column is always for the events of the lesson, while other(s) for the remarks in close connection with the events.

- The main part of the document can be followed by an appendix, containing handouts, boardwork, tests, etc.

Although, the two texts of the two surveys are different both in structure and length, they both were sufficient to test basic word processing skills. In addition, the second text was meant to reveal advanced word processing skills also. My expectations were higher ten years after the first test, because during the past ten years computers have become unavoidable and essential. I should mention that I was not the only one expecting more with the passing years. We read in 1997 ([19]) that "It will not be long until using word processors will be so 


$$
\text { "tmcs-csernoch" — 2010/11/14 — 22:08 — page } 250 \text { — \#4 }
$$

widespread that it becomes part of our culture. 'Modern illiteracy' will not mean that someone cannot read or write rather that the person cannot word process." 1

I thought that ten years could be considered as 'not long', so it was high time to launch a new test, and see the results.

\subsection{Summary of the results of the 1997 survey}

After analyzing the data of the 1996-1997 survey it was clear that we were facing serious problems. Only $12 \%, 3 \%$, and $20 \%$ of students who studied word processing in school, on their own, or were senior students of Informatics, respectively, were able to correctly finish the task. It was clear that the school does have some influence on the students, and that the results of the senior students of Informatics was devastating, suggesting that we would not have teachers in the near future who would be able to teach word processing in schools.

\section{The results of the 2005-2006 survey}

\subsection{Number of students, documents}

In the 2005-2006 survey the works of 101 students were analyzed. However, the number of the documents handed in was much higher than the number of the students. I received 146 documents from the 101 students. The difference between the number of students and documents is explained by the fact that the students were not able to save the three parts in a single document. There were 21 students who handed in more than one documents, and among the 80 students, who attached only one document, 13 students did not have the compulsory opening page. The numbers add up to 34 , which is approximately the third of the students.

98 students used Microsoft Word, 3 students used Microsoft Excel (from now on MS Word, MS Excel, respectively), and only one student used TEX. The document generated in $\mathrm{T}_{\mathrm{E}} \mathrm{X}$ was left out from the analysis, and only the Microsoft documents were included in the survey.

\footnotetext{
${ }^{1}$ Translated from the original by the author.
}

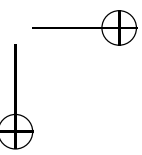




$$
\text { "tmcs-csernoch" — 2010/11/14 — 22:08 — page 251 — \#5 }
$$

\subsection{Using Microsoft Excel as a word processor}

The selection of the software is not the key figure in this project. The selected software - a spreadsheet in this case - can be used properly even if it is not designed for this purpose, or the other way around, the appropriate software - a word processor in this case - can be used in a completely inappropriate way, if the user does not have any idea about the proper usage of the software.

Three students chose MS Excel to carry out the task. If the formats of the cells are set properly, Text control to Wrap text, MS Excel is a perfect selection to create parallel columns. Two of the three students using MS Excel had a false idea about word processing. Their documents cannot stand any modification, which means they are incorrectly formatted. In addition to the incorrect number of table rows and the incorrect settings of the cells, the SPACE character is used extensively in both documents.

What is however interesting, even the student who set the cell formatting correctly in MS Excel created a Word document for the title page, as did the other two students who used MS Excel incorrectly.

\subsection{Margins}

In the 1996-1997 survey I found that students have no clear understanding of the concepts of margin and indents. $28 \%, 41 \%$, and $11 \%$ of the students, who studied word processing in school, studied on their own, or were the senior students of informatics, respectively, mistook margin for indent ([4]). Unfortunately, I also found in a competition of Applied Informatics that the two concepts are used synonymously $([7])$. Since setting the page and the margins of the document might be crucial in the processes of word processing, similarly to the first survey, in the second, I started the analysis with the page settings - Paper size and Margins.

The margins in most of the documents are set correctly, but we still have $20 \%$ of the students who do not know how to set and use the margins. In their documents the size of the margins varied, even within a document, between the strangest limits $(0.63 \mathrm{~cm} \leq$ margin $\leq 5.08 \mathrm{~cm})$.

Furthermore, it became clear that setting the margins correctly is not a guarantee for their proper use. I found 40 documents where the text was expanded beyond the borders of the text area, and as a result, text appeared on the margins. SPACES were expanded beyond borders, which was found a relatively common, 


$$
\text { "tmcs-csernoch" — 2010/11/14 — 22:08 — page } 252 \text { — \#6 }
$$

though unnecessarily applied, method. The right Indent was set to negative values, the pictures were hanging over the borders of the text area on both sides, or the tables were expanded beyond these borders. Letting text on the margins is dangerous because printers do not use the edge of the papers for printing, so text can be lost ([9], [10]).

\subsection{Page breaking, number of pages, number of files}

The next question was how students handled the pages, how they advanced from one page to the next. Originally it was not planned, but I had to deal with the empty pages which appeared more frequently in the documents than it was expected.

When the text is not continuous the question arises how to get to the following page. Page break is hardly used to get to the next page, instead, $70 \%$ of the students used the ENTER character, exclusively, to reach the next page. It is incorrect according to the definition of the properly formatted text, because these texts cannot stand any modification ([7]). If the user will add/delete paragraphs to/from the text the number of the empty paragraphs will also have to be changed manually, which means unintended re-formatting.

As it was mentioned in Chapter 3.1 several students were not able to create only one document, instead they saved the separate parts of the Closing lesson plan in separate files. The maximum number of files was six.

Several documents contained empty pages. Originally, I did not mean to pay attention to the number of pages, but it was more frequent than I have ever thought. Altogether 25 documents were found, which had empty pages.

\subsection{Header, footer, and numbering pages}

There was only one student who used Header at all, and it was correctly used. There was another student who was trying to use Footer, but it turned out to be incorrect.

Altogether 42 students used page numbers. 39 were correct, one put them on the bottom of the pages in the text area, and two combined the correct and the incorrect solutions, which means that almost $40 \%$ of all the students used the page numbering correctly.

However, there was not a single student to use table headings correctly Heading Rows Repeat. All students who ventured into this field put the table heading on every single page by hand, breaking the page and/or the table, and 
then inserting a new table row on the top of the consequential page. This solution is incorrect, because this way the text cannot stand any modification ([7]). By deleting/inserting text to/from the document, this quasi table heading will move up and down on the pages.

\subsection{Hyphenation}

Hyphenation would be recommended in texts with either newspaper or parallel columns, in texts where the number of columns is more than one, so the lines are shorter than the area between the two margins. There were only seven students who at least thought that hyphenation would be good, but only one of them used it correctly - a student of Informatics. The other six students used manual hyphenation, which is completely incorrect ([7], [11]).

These manual hyphenations are incorrect, due to several reasons. First of all, the word chunks created this way are not in the dictionary of the spell-checker, so most of the manually hyphenated word chunks are marked as syntactically incorrect, which raises the probability of syntax errors in the text. Besides this, any modification of the text moves the dash character from the end of the line.

\subsection{Parallel columns}

The robust part of the Closing lesson plan should be arranged into parallel columns ([7], [10], [21], [22]), where the number of columns varies from two to six, depending on the requirements of the subject.

This turned out to be one of the most challenging formatting. Since MS Word does not handle parallel columns directly $([10])$, the students had to find out how to substitute them. Their imagination is far beyond any expectations.

Out of the 101 students 79 used tables, which should have been the solutions.

However, none of the methods listed in Chapters 3.7.1.1-3.7.1.2 can be accepted as correct, because they cannot bear any modification ([7]). If one would dare to make a correction in one of the 'columns' the texts in the other columns will then slide up or down, and never again will be at the same vertical position.

\subsubsection{Incorrect solutions to substitute parallel columns}

Many different 'solutions' were invented to create real and quasi parallel columns. In the following chapters these solutions are presented. Altogether 21 correct solutions arrived, which means that about $80 \%$ of the solutions were incorrect. 


$$
\text { "tmcs-csernoch" — 2010/11/14 — 22:08 — page 254 — \#8 }
$$

\subsubsection{Imitating typewriters}

An incorrect solution is a strange combination of typewriters and word processors. The students inherited all the bad habits from the typewriter's era and added to this a feature hardly used in this context - Text Box.

Dealing with the graphical objects of the documents was not the subject of this analysis. However, it was found that not locking the anchor of the objects and the incorrectly chosen layout of the objects are the most commonly encountered mistakes in connection with the graphical objects.

\subsubsection{Newspaper columns}

Another incorrect solution is to substitute parallel columns with newspaper columns. The first problem is, that there is no guarantee that the first column contains about as much text as the second, and the third, etc., so text slices intended to a column can easily slide into the next or the previous column ([7]). If one makes a correction, for example, in the first column MS Word tries adjusting the height of the columns. As a result, all the texts which seemed parallel before the correction are moved from their original vertical position. The result is simply a chaos. The other problem is that adding as many section breaks as necessary to substitute the table rows in such a long document takes a lot of time and still fragile to modification.

\subsubsection{Tables}

Out of the 79 students who used tables, only 21 students used the table and the table rows correctly. As it was mentioned in Chapter 3.2, out of the 79 students three used Excel, and among them only one was correct.

Even creating a table is not a guarantee for a good solution. I found solutions from carrying only one row, up to tens of unnecessary rows and anything in between.

Inserting fewer rows than needed made the students use the ENTER character intensively, which again is incorrect, because by applying this solution the text becomes fragile and cannot stand any modification ([7]).

Using more rows than needed brakes up the sentences into chunks, and again the text cannot be modified, because after the modification the once parallel texts will not be parallel any more. 


$$
\text { "tmcs-csernoch" — 2010/11/14 — 22:08 — page } 255 \text { — \#9 }
$$

\subsection{Paragraph formats}

In this chapter I will focus on the formats whose domain is the paragraph. I only selected those formats which were necessary for the Closing lesson plans: Alignment, Indentation, Space Between Paragraphs, Bullets and Numbering, Tabs.

The students not only had problems with decisions involving text-level formatting, they also applied solutions on paragraph-level which are completely against the definition of the properly formatted text $([7])$.

\subsubsection{Alignment}

One of the basic paragraph formats is alignment. Surprisingly, several students had serious problems with the center and the right alignment, they were not able to click on the corresponding button or choose from the right menu ([9], [14], [16], [18], [21], [22]). Instead, they used the SPACE and TAB characters intensively.

\subsubsection{Indents}

The other critical point of word processing is the indentation of paragraphs. In many cases TABS and SPACES are used instead of Indentation. These solutions are, again incorrect $([7])$, because "... the tabs would move with the text as you edited the paragraph" ([21]).

\subsubsection{Bullets and Numbering}

To add either an ordered or unordered list to a piece of text, again, seemed to be a challenging task, in spite of the fact that MS Word tries recognizing them. Why people do not use Bullets and Numbering is hard to explain. On the one hand, the command is easy to apply - especially since MS Word recognizes it -, on the other hand, the list can be modified any time, without renumbering the whole list ([7], [9]). The latter reason should overrule any other old, bad habits, but as it was found, it does not, which I cannot find an explanation for.

\subsubsection{Positioned tabs}

Using more than one alignment in a single row seems one of the most challenging tasks. As it was shown in Chapter 3.8.1 even the paragraph alignment was too much to apply properly. It is no wonder, therefore, that more than one alignment proved for most of the users an undoable task. The result was disastrous. I experience the same in my school. The students have no idea why and 


$$
\text { "tmcs-csernoch" — 2010/11/14 — 22:08 — page 256 — \#10 }
$$

how to use the tabulators properly. To reach an acceptable level always takes a lot of time, longer than any other part of word processing.

Unfortunately, using positioned tabs - tab stops ([7], [9], [16], [18], [20], [21], [22]) - are one of the rarest in these documents. In none of the texts were the space holders for the signatures correct, all the students made some mistakes to different degrees. One of the best solutions was where the student created her own tab positions, but was not able to carry along correctly, and finally she used the UNDERSCORE characters to complete the task. What is sad is that her major was Informatics, and even she was not able to give a right solution to this problem.

None of the students realized that the space holders for the signature could have been carried out with table also.

\subsubsection{Character formats}

There is not much to say about the applied character formats, because I do not know anything about the intention of the students, I have no idea what they wanted to emphasize. So I did not dare to analyze the texts from the aspects of typography. One feature, however, is worth mentioning, namely the intensive usage of Underline. The underlining is not recommended typographically, but it is used so often that I thought it is worth mentioning ([20]). When I asked my students why they used it, the answer was always the same: the button is on the Formatting toolbar. This explanation, however, is weak, because the Alignment buttons, the Bullets and Numbering buttons, etc. are also there, but they just ignore them.

In general, the analyzed texts held several serious typographic mistakes, but as I mentioned, without knowing the intentions of the authors I do not dear to evaluate them. The other reason not dealing with the typographic mistakes was that it is far beyond the aims of this analysis and the limitations of this article. What is, however, obvious from the works of the students that they ignore the rules of typography, which is a great mistake ([12]).

\subsubsection{Language}

To set the language of a text or a text slice should be fundamental. However, among the foreign language students the number of those who set the language properly was less than those who did not. Setting the language would have saved them from some syntactic errors. 


$$
\text { "tmcs-csernoch" — 2010/11/14 — 22:08 — page } 257 \text { — \#11 }
$$

\subsubsection{Equations}

As I mentioned above (Chapter 3.7.1.1), originally I did not mean to analyze the pictures, graphical objects, equations, but after seeing the works of the students I decided to mention them. Neither the students of Mathematics nor those of Informatics performed any better than other students. Handling the equations, however, caused them real problem.

By the nature of the subject all who had performed these were students of Mathematics and among them some were also students of Informatics. In these solutions the word processor and equation editor are used in a strange combination. Finding symbols - e.g. $\sqrt{ }$ and $\notin-$ caused problem. The student did not know that they are among the Symbols and there is no need for inserting equations for these signs. On the other hand, the students did not find the '=' sign in the equation editor among the sings - which is true, because it is not there, since it is on the keyboard - so the solution was to break up the row of equations with the '=' signs.

\subsubsection{Total ignorance}

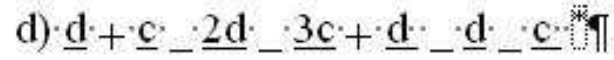

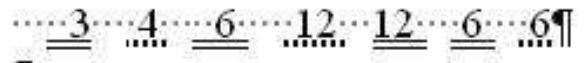

$$
\begin{aligned}
& \text { \ा } \\
& =\underline{4 d}-\underline{4 d}+\underline{d}-2 \underline{2 d}+\underline{3 c}-3 \underline{3 c}-2 \underline{c} \cdot{ }^{*} \text { I } \\
& \cdots 12 \cdots 12 \cdots 12 \cdots 12 \cdots 12 \cdots 12 \cdots 12 \text { T } \\
& \text { 【 }
\end{aligned}
$$

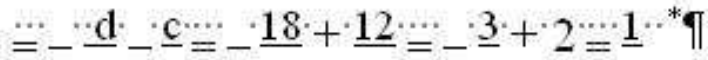

$$
\begin{aligned}
& \cdots \cdots 12 \cdots 6 \cdots \cdots \cdot 12 \cdots 6 \cdots \cdots \cdot 2 \cdots \cdots \cdots \cdot 2 \text { ा }
\end{aligned}
$$

Figure 1. Creating equations without using the Equation Editor

However, the solution presented in Fig. 1 did not use the equation editor at all to create the equations. Here the student - again I would like to emphasize that she was a senior student of Informatics, whose job would be in the following year to teach word processing - found that for creating a fraction the only way is to insert the nominators in a paragraph, add an Underline style to them, and 


$$
\text { "tmcs-csernoch" — 2010/11/14 — 22:08 — page 258 — \#12 }
$$

then in the following paragraph add the denominator with some extra SPACES to position the denominators right below the corresponding nominators. Other unexpected solutions can be found in Fig. 1, which again show the ignorance of the student. The minus sign is substituted with an UNDERSCORE character, the plus signs and the whole number (in equation 3) is formatted to Subscript style to lower them, and finally, the equation sign is substituted by Double Underlined SPACES.

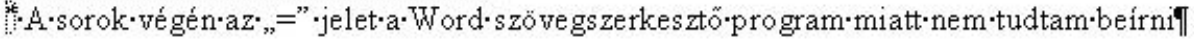

Figure 2. Blaming the word processor for not being well enough for the user's purposes: 'At the end of the lines I was not able to add the '=' signs because of the Word'. ${ }^{2}$

However, the student was not really satisfied with the MS Word, because she added a footnote to the first 'equation' blaming the MS Word that it did not allow her to add '=' signs at the end of the lines (Fig. 2). The ignorance of the student was so enormous that she found it right to blame something or someone else not allowing her to complete the task.

\subsection{Syntactic}

To avoid syntactic mistakes not only the language of the document - or shorter sections of it - has to be set properly, but the user has to be familiar with the syntactic rules of the language (for the Hungarian language see [15]). Without such basic knowledge the text would never reach a satisfactory stage ([2], [8]).

The analyzed documents were loaded with syntactic mistakes. However, I focused on the mistakes of students of Hungarian and Informatics, who both should be well aware of their mother tongue. One will teach Hungarian, the other will teach word processing as a practicing teacher, and in both cases the final products of their job are texts. It is so disappointing and shameful when a text is full of syntactic mistakes, and the most disappointing when someone who does not know these rules is trying to teach them.

The documents created in MS Excel carry more syntactic mistakes than those which came to life by using word processors, which strengthen the statement that using a spell checker is most welcome even if they are not $100 \%$ correct.

${ }^{2}$ Translated from the original by the author.
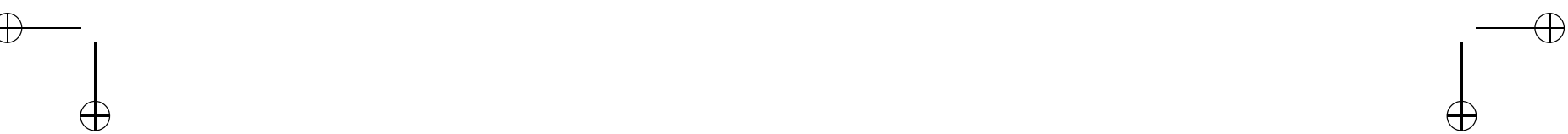
Facing all these fundamental mistakes I am convinced that they should not have appeared in the works of senior university students.

\section{Conclusions}

With the two surveys, which I carried out ten years apart, my feeling, my every day experience seems to be proved that proper word processing is not part of our culture, students whom I met have serious problems using any of the word processors properly. In both surveys I have tested documents created with MS Word, but I do not think that the type of the word processor has any importance.

In the two surveys there was difference between the size of the text, and also in the word processing tools, which should have been applied. However, I am convinced that in spite of the differences between the two texts their 'realizations' are comparable.

The mistakes show that the students were not familiar even with basic word processing tools. Ten years ago we had some excuses for the results because some of the students had no chance to learn word processing at school, so they used it more or less spontaneously. However, the students tested in the second survey had Computers or Informatics classes at school, many of them on more than one level of the school system - elementary school, high school, college, university. Consequently, they should have had a chance to learn word processing. The solutions, which we have seen are totally disappointing. The question is what they learned during those classes, why they are not familiar even with the basic concepts of word processing? The answer again lies in the survey, since we have seen that senior students - whose job in the following years would be to teach computers and informatics - were as ignorant as the rest of the class. If they do not know how to use a word processor in their senior year of the university, how can we expect them to teach elementary and high school students in the upcoming years, after leaving university.

After analyzing the works of the students I wanted to find further explanations for their failure. I did not mean to put the responsibility on the shoulders of others - e.g. teachers, school system, etc. -, since their mistakes are theirs, but to find explanations for this general misinterpretation.

Along the two surveys I was trying to follow up the influence of teachers. It was clear after the two surveys that those students performed better where the active presence of the supervising teachers was obvious. In the second survey the works of those senior students proved to be a lot better whose supervising 


$$
\text { "tmcs-csernoch" — 2010/11/14 — 22:08 — page } 260 \text { — \#14 }
$$

teachers also use the word processor properly, and helped the students during their practice. The lesson plans were not perfect, but lacked the basic mistakes, and so were essentially acceptable. Another source of help came from the foreign language departments, where the students were told to use table for the parallel columns, so at least the structure of their documents was correct. I have found traces of help only in these two cases. What about the others?

Who is to be blamed for this failure? The last fifteen, twenty years did not prove to be enough to make it clear that 'being a modern illiterate' is as much a shame as being an illiterate. First of all, the teachers of Informatics are responsible, but as we have seen even those who have left the university in recent years are as ignorant as other students, so there is not much hope that they will do better than their predecessors. The next question is who is to be blamed for the ignorance of the teachers of Informatics? The responsibility of those institutes is great that give license for them to teach. As we have seen from the above examples, they are not qualified for being a teacher of Informatics, they only have a piece of paper and do what they think is right, what their ignorance and conscience allows them to do.

What is sure, as long as the teachers of Informatics are not qualified to teach word processing techniques, there is no hope, because bad examples will circulate among the students. On the other hand, the jobs in connection with word processing should be divided up among the teachers of different subjects. To teach the syntactic and semantic requirements of the texts the teachers of languages mother tongue and foreign language teachers also - are better qualified than the teachers of Informatics. In a similar way, to teach the rules of typography the teachers of Arts have more rights than the teachers of Informatics, and last but not least this whole process would be fasten up if the students would know how to type.

I think the teachers of different subjects should all be familiar with the concept of the properly formatted text, at least with basic word processing techniques, the syntactic and semantic requirements of the texts, and also with the typographic rules. In addition to these requirements those should teach the students the details who are best qualified to do it. 


\section{References}

[1] L. Brezsnyánszky, Tájékoztató a Debreceni Egyetem tanárképzési rendjéről, Debreceni Egyetem, Debrecen, 2004, http://www.detek. unideb.hu/tekeh/tanarkepzes/zarotanitas.htm.

[2] Gy. Bujdosó and M. Csernoch, Valójában kik vizsgáztak le szövegszerkesztésből? Vizsga- és versenyfeladatok patológiája és diagnosztikája (Patology and diagnosis of tests on word processing), 2008, http://www .agr .unideb.hu/if2008/kiadvany/papers/B54.pdf.

[3] Csernoch, L-né, Hogyan készítik fel az egyetemek, föiskolák a tanárszakos hallgatókat az informatika, számítástechnika tantárgy tanitására, Informatika a Felsőoktatásban '96 - Networkshop '96, Debrecen, 1996, 499-503.

[4] M. Csernoch, 3rd International Conference on Applied Informatics, Eger-Noszvaj, 1997, 375-382.

[5] M. Csernoch, Az ötödéves tanárjelöltek szövegszerkesztési kultúrája, Mit? Kinek? Hogyan? Vezetőtanárok III. Országos Módszertani Konferenciája, Budapest, 2006, 111-122, ISBN: 9630609649.

[6] M. Csernoch, A szövegszerkesztés-oktatás hatékonyságának változása az elmúlt 10 évben (Changes in the efficiency of teaching word processing in the last ten years), 2008, http://www.agr.unideb.hu/if2008/kiadvany/papers/A61.pdf.

[7] M. Csernoch, Teaching word processing - the theory behind, Teaching Mathematics and Computer Science 7/1, 2009, 119-137.

[8] M. Csernoch and Gy.Bujdosó, Vizsga- és versenyfeladatok szövegbeviteli hibái és ezek következményei, ÚPSZ 1 (2009), 19-40, http://www.ofi.hu/elemek/userfiles/200901_web.pdf.

[9] L. Csernoch and Csernoch L-né, Word 6.0 gyakorlatok I., Nemzeti Tankönyvkiadó, Budapest, 1998.

[10] L. Csernoch and Csernoch L-né, Word 6.0 gyakorlatok II., Nemzeti Tankönyvkiadó, Budapest, 1998.

[11] F. Devecz K. Jónás, T. Juhász, R. Kévés, Z. Reményi, G. Siegler and B. Takács, Irány az ECDL! a középszintü érettségi, Nemzeti Tankönyvkiadó, Budapest, 2004.

[12] D. Jury, About Face: Reviving the rules of typography, Rotovision, 2004.

[13] Kerettanterv, Vol. 28/2000, (IX. 21.), 2004, OM rendelet, http: //www.okm.gov.hu/letolt/kozokt/torvenytar/2000_280M.doc.

[14] Cs. Kiss and A. Krnács, Szövegszerkesztési ismeretek, Müszaki Könyvkiadó, Budapest, 2001.

[15] MHSZ, A magyar helyesírás szabályai, 1985, Tizenegyedik kiadás, Második (változatlan) lenyomat, http://mek.niif.hu/01500/01547/01547.pdf.

[16] Microsoft (1993) User's Guide., Microsoft Word, Microsoft Corporation.

[17] NAT (Nemzeti Alaptanterv), 1995, www. oktatasjog. extra.hu/jog/130_1995kormrNAT.pdf. 


$$
\text { "tmcs-csernoch" — 2010/11/14 — 22:08 — page } 262 \text { — \#16 }
$$

[18] Topsec Informatikai és Oktatási Kft., Szövegszerkesztés. Microsoft Word XP, Informatikai és Hírközlési Minisztérium, Budapest, 2004.

[19] T. Tóth, A szövegszerkesztés alapjai, Nemzeti Tankönyvkiadó, Budapest, 1997.

[20] P. Virágvölgyi, A tipográfia mestersége számitógéppel, Osiris Kiadó, Budapest, 2004.

[21] WordPerfect, WordPerfect Workbook for IBM Personal Computers and PC Networks, WordPerfect Corporation, 1989.

[22] WordPerfect, WordPerfect Reference for IBM Personal Computers and PC Networks, WordPerfect Corporation, 1990.

MÁRIA CSERNOCH

UNIVERSITY OF DEBRECEN

4010 DEBRECEN, P. O. BOX 12

HUNGARY

E-mail: mariacsernoch@hotmail.com

(Received December, 2009) 